\title{
Root system and root and stem base organic reserves of pasture Tanzania grass fertilizer with nitrogen under grazing
}

\section{Sistema radicular e reservas orgânicas de raízes e base do colmo do capim Tanzânia fertilizado com doses de nitrogênio sob pastejo}

\author{
Cecílio Viega Soares Filho' ${ }^{*}$; Ulysses Cecato ${ }^{2}$; Ossival Lolato Ribeiro ${ }^{3}$; \\ Cláudio Fabricio da Cruz Roma ${ }^{4}$; Clóves Cabrera Jobim²; Tatiane Beloni ${ }^{5}$; \\ Silvia Helena Venturoli Perri ${ }^{1}$
}

\begin{abstract}
The goal of this study was to evaluate the concentrations of non-structural carbohydrate (NSC) and of total nitrogen $(\mathrm{N})$, as well as, to evaluate the root system in Tanzania-grass pastures fertilized with doses of urea in fall, spring and summer. The experiment was conducted at the Experimental Farm of Iguatemi, Maringá, Paraná, Brazil, from March 2007 to March 2008. The experimental design was complete random blocks with subplots and four repetitions. The plots showed doses of $\mathrm{N}(50,100 \mathrm{e} 150$ $\mathrm{kg} \mathrm{ha}^{-1}$ of $\mathrm{N}$ ) plus the control (no N fertilization), and the subplots the season of the year. Root samples were taken at depths of 0-10, 10-20 and 20-40 cm. Root biomass showed a trend for mass accumulation up to a dosage of $100 \mathrm{~kg} \mathrm{ha}^{-1}$ for all seasons evaluated. Also, about $80 \%$ of the root system of Tanzaniagrass plants was found on the $0-10 \mathrm{~cm}$ layer for all dosages of $\mathrm{N}$. Nitrogen fertilizer above $100 \mathrm{~kg} \mathrm{ha}^{-1}$ may foster fast forage plant growth reducing its NSC root storage capacity although favoring NSC and total N storage at stem base. NSC and total N concentrations were highest in fall, demonstrating that its usage is greater in spring due to the weather conditions being favorable to plant growth. In the regrowth, the largest reserve of total $\mathrm{N}$ was at the $0-10 \mathrm{~cm}$ root layer and the largest NSC reserve is at stem base. Key words: Panicum maximum, non-structural carbohydrates, total nitrogen, root biomass
\end{abstract}

\section{Resumo}

O estudo objetivou avaliar as concentrações de carboidratos não estruturais $(\mathrm{CNE})$, nitrogênio $(\mathrm{N})$ total e avaliação do sistema radicular em pastagem de capim-Tanzânia adubada com uréia em diferentes doses nas estações de outono, primavera e verão. O experimento foi conduzido na Fazenda Experimental de Iguatemi, Maringá, PR, no período de março de 2007 a março de 2008. O delineamento experimental utilizado foi de blocos completos ao acaso, com parcelas subdivididas com quatro repetições. Foram usadas como parcelas, as doses de N-uréia (50,100 e $150 \mathrm{~kg} \mathrm{ha}^{-1}$ de N-uréia) e, como subparcelas, as estações do ano. As amostragens das raízes foram realizadas nas profundidades de 0-10, 10-20 e 20-40 $\mathrm{cm}$. A biomassa radicular apresentou tendência de acúmulo de massa até $100 \mathrm{~kg} \mathrm{ha}^{-1} \mathrm{de} \mathrm{N}$ em todas as

\footnotetext{
${ }^{1}$ Profs. Drs. Universidade Estadual Paulista, UNESP, Faculdade de Medicina Veterinária, Campus de Araçatuba, Dept ${ }^{\circ}$ de Apoio, Produção e Saúde Animal, Araçatuba, SP, Brasil. E-mail: cecilio@fmva.unesp.br; shperri@fmva.unesp.br

${ }^{2}$ Profs. Drs. do Dept $^{\circ}$ de Zootecnia, Universidade Estadual de Maringá, UEM, Maringá, PR, Brasil. E-mail: ucecato@uem.br; ccjobin@uem.br

${ }^{3}$ Prof. Dr. do Dept ${ }^{\circ}$ de Zootecnia, Universidade Federal da Bahia, UFBA, Salvador, BA, Brasil. E-mail: ossribeiro@hotmail.com

${ }^{4}$ Zootecnista, M.e em Zootecnia, Técnico Empresa Tortuga, Rondônia, RO, Brasil. E-mail:claudio zoo@yahoo.com.br

${ }^{5}$ Zootecnista, M.e em Zootecnia, Dept ${ }^{\circ}$ de Zootecnia, UEM, Maringá, PR, Brasil. E-mail: tati_zoo@hotmail.com

* Author for correspondence
} 
estações avaliadas. Independente da dose de $\mathrm{N}$ utilizada cerca de $80 \%$ do sistema radicular do capimTanzânia estava concentrado na camada de $0-10 \mathrm{~cm}$ de profundidade. A adubação nitrogenada acima de $100 \mathrm{~kg} \mathrm{ha}^{-1}$ pode estimular o crescimento acelerado da planta forrageira, reduzindo sua capacidade de armazenamento de CNE nas raízes. No entanto, favorecem o armazenamento de CNE e $\mathrm{N}$ total na base do colmo. As concentrações de $\mathrm{CNE}$ e $\mathrm{N}$ total foram mais elevadas no período do outono, demonstrando que sua utilização é maior na primavera devido às condições climáticas favoráveis ao crescimento da planta. Na rebrota, a planta apresentou maior reserva de $\mathrm{N}$ total na camada de 0-10 $\mathrm{cm}$ das raízes, bem como maior reserva de CNE na base do colmo.

Palavras-chave: Panicum maximum, fertilizante nitrogenado, pastagem, carboidrato não estrutural, $\mathrm{N}$ total, biomassa raízes

\section{Introduction}

The study of the root system is a current investigation because it is an effective parameter for the evaluation of the effects of soil usage, particularly when concerning the soil-plant system (PAGOTTO; IMHOFF; CORSI, 2002). Roots are the link between the soil and the plant's aerial parts.

However, little is known about their root system morphology and biomass production (BATISTA; MONTEIRO, 2006b), mainly because it is difficult to create a methodological standardization of the study of root development. Root production and turnover are directly related to the carbon and nutrient recycling. However, not much is known about the dynamics of pasture root system specially due to the technical difficulties inherent to such investigations studies (GUENNI; MARIN; BARUCH, 2002).

Nevertheless, the realization of its importance to pasture production and persistence has made the root system an important issue in pasture handling since the issue of new tillers, leaf expansion and the surviving leaf area lead to a quick and vigorous regrowth of the forage plant. Results concerning reserve carbohydrates are still quite controversial. The level of non-structural carbohydrates may decrease after a cut or defoliation but some authors argue that the nutrient translocation from root to plant is of little significance (HUMPHREYS, 1991). That is to say the plant becomes dependent on reserves only when the remaining leaf area is not enough to photo-synthesize new product and keep growth going on.
The physical conditions of soil, nutrients, humidity, temperature and defoliation degree affect forage production significantly. However those factors act directly on the root system which is the support and base for the development of tillers and leaves and therefore forage production. Nonstructural carbohydrates (NSC) are used by the plant as a nutrient for its up-keeping and future development of tillers and roots and must therefore be studied as well.

Another component that acts as organic reserve and bear influence on the plant's NSC is nitrogen (N). Volenec, Ourry e Joern (1996), report results for grasses where the storage of $\mathrm{N}$ contributed to the regrowth of the aerial part. However, N application may also promote changes in the NSC levels of forage plants, causing a reduction in those reserves because it encourages growth, thus using up compounds accumulated in the roots and in the stem base. This fact justifies the study of the behavior of those reserves, especially regarding fertilizer tropical grasses since such studies are rare in Brazil.

The study of the grass root system and of the factors that bear influence on it is fundamental to the definition of criteria for viable handling practices and to the assurance of pasture persistence. Thus, the goal of this work was to evaluate the root systemtem and the concentrations of NSC and of total $\mathrm{N}$ in Tanzania grass pastures fertilizer with $\mathrm{N}$ under grazing conditions in fall, spring and summer. 


\section{Material and Methods}

The experiment was carried out in a Panicum maximum $\mathrm{cv}$. Tanzania pasture on an experimental area of the Iguatemi Experimental Farm, Maringá State University, Maringá, state of Paraná, Brazil, ( $23^{\circ} 25^{\prime} \mathrm{S} ; 51^{\circ} 57^{\prime} \mathrm{W}$ and $550 \mathrm{~m}$ a.s.1.). According to
Corrêa (1996), by the Köppen classification, the local climate is Cfa subtropical humid mesothermal with hot summers, and summer-dominant rainfall. The weather data for the experimental period were collected at a meteorological station and are shown in Figure 1.

Figure 1. Monthly highest and lowest air temperature $\left({ }^{\circ} \mathrm{C}\right)$ and rainfall $(\mathrm{mm})$ means for the experimental period $(2007 / 2008)$.

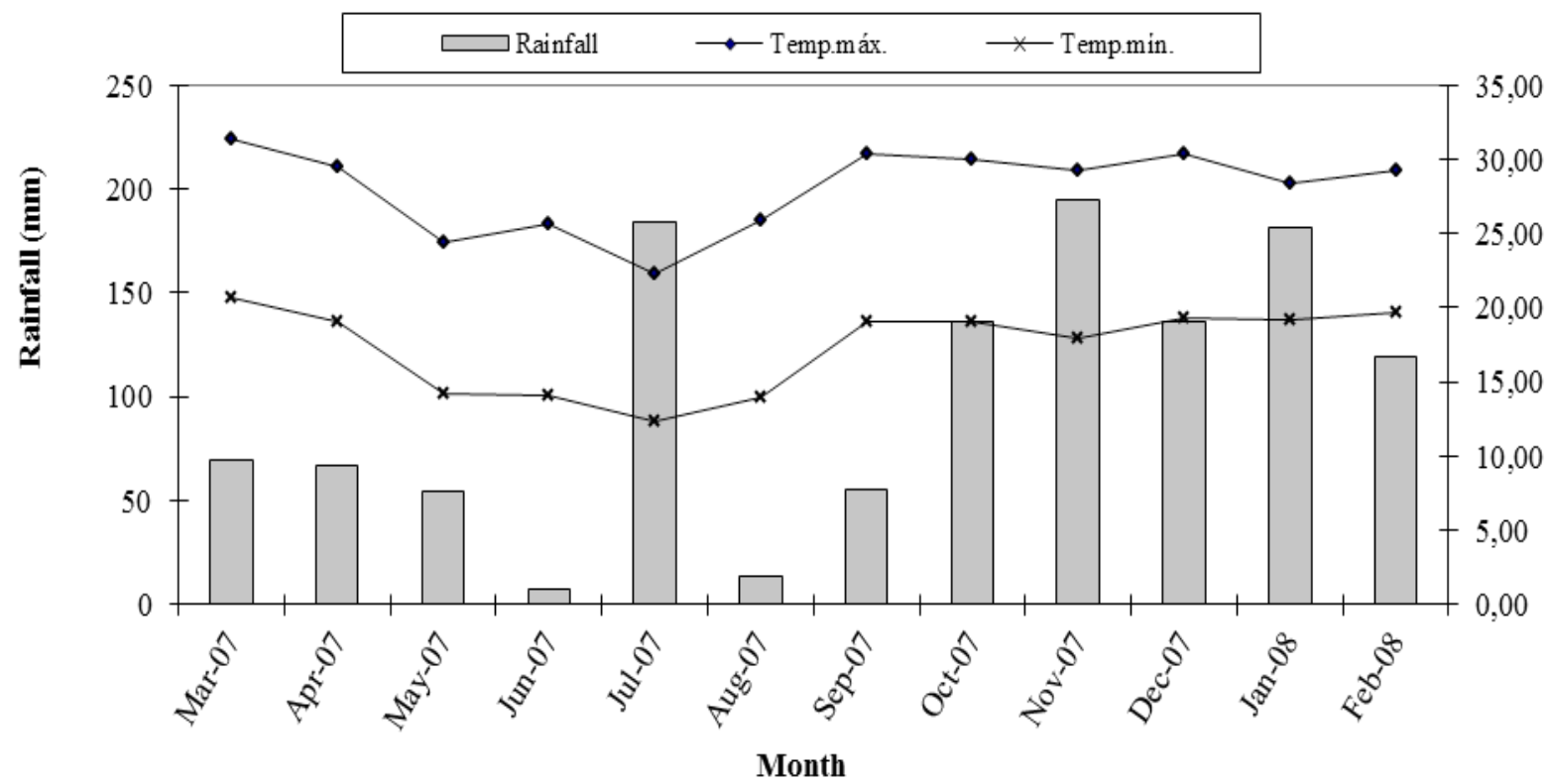

Source: Elaboration of the authors.

The soil at the experimental area is of type dystrophic red latosoil (EMBRAPA, 2006) with the following chemical characteristics: $\mathrm{pH} \mathrm{CaCl}_{2}: 4.8$; $\mathrm{P}$ (ion-exchange resin extraction method) $=9.0 \mathrm{mg} /$ $\mathrm{dm}^{3}$; Carbon organic $=12.7 \mathrm{~g} \mathrm{dm}^{-3} ; \mathrm{Ca}=1.0 \mathrm{cmol}_{\mathrm{c}}$ $\mathrm{dm}^{-3} ; \mathrm{Mg}=0.7 \mathrm{cmol}_{\mathrm{c}} \mathrm{dm}^{-3} ; \mathrm{K}=0.09 \mathrm{cmol}_{\mathrm{c}} \mathrm{dm}^{-3}$; cation exchange capacity $=4.8 \mathrm{cmol}_{\mathrm{c}} \mathrm{dm}^{-3}$ and base saturation $=38.6 \%$. At the experiment outset the soil was corrected with $40 \mathrm{~kg} \mathrm{ha}^{-1}$ of $\mathrm{P}_{2} \mathrm{O}_{5}$ as simple superphosphate $\left(18 \%\right.$ of $\left.\mathrm{P}_{2} \mathrm{O}_{5}\right)$. Acidity correction was done with dolomitic limestone in order to raise base saturation to $60 \%$ according Werner et al. (1996).

The experimental design was completely randomized blocks with plots subdivided into collection depth with four repetitions. The plots showed the doses of $\mathrm{N}\left(50,100\right.$ and $150 \mathrm{~kg} \mathrm{ha}^{-1}$ of $\mathrm{N}$ ) plus the control (no $\mathrm{N}$ fertilization), and the subplots showed the root collection depth $(0-10 ; 10$ 20 and 20-40 cm) with three repetitions. Treatment application was analyzed from collections carried out about fourteen days after pasture fertilization. Urea was thrown in the parcels early in the morning following livestock removal from the picket.

Nitrogen (as urea, 46\% N) was applied in fall (April 18, 2007), spring (November 12, 2007) and summer (January 24, 2008) by sprinkling over the plots early in the morning of the day after all animals were removed from the fenced area. Together with the first $\mathrm{N}$ application $60 \mathrm{~kg} \mathrm{ha}^{-1} \mathrm{~K}_{2} \mathrm{O}$ was applied as potassium chloride $\left(60 \% \mathrm{~K}_{2} \mathrm{O}\right)$. 
The experiment was set up in a $1.600 \mathrm{~m}^{2}$ area divided into 16 pickets, every two pickets sharing a water dispenser and separated by a passageway designed to facilitate livestock transit to the handling center, each of them with a mean area of $100 \mathrm{~m}^{2}$. Each picket was grazed in a rotary system with one and a half day of occupation and a resting period defined by the treatment applied. Livestock entered a picket when the pasture was about $70 \mathrm{~cm}$ high and would leave a residue about $30 \mathrm{~cm}$ high, with 27 rest days in spring and summer, according Barbosa et al. (2007). Female calves with a live weight about $300 \mathrm{~kg}$ were used as handling tool.

The root system evaluations were carried out in fall, spring and summer. The root biomass of the stratified grass was determined at depths of $0-10$, $10-20$ and $20-40 \mathrm{~cm}$ from three subsamples per plot, using a $50 \mathrm{~cm}$-long $10 \mathrm{~cm}$-diameter steel cylinder tube with an opening in the middle to facilitate sample stratification. The samples were packed in resistant plastic bags, identified and promptly stored at $-5^{\circ} \mathrm{C}$ in a cold room.

Roots were washed in running water in $1 \mathrm{~mm}$ mesh until no signs of soil contamination were present and immediately placed in water-alcohol $20 \%$ solution for 12 hours for a posterior drying with forced air at $65^{\circ} \mathrm{C}$ until a constant weight was reached. Diameter, mass and length readings were obtained after being washed in running water were carried out with a Delta T Scan with root imaging and analysis software.

At the same place of root collection stem base samples were collected standardized at $10 \mathrm{~cm}$ from ground level of soil surface. The collected material was taken to an oven and received forced air at $105^{\circ} \mathrm{C}$ for one hour in order to inhibit cellular breathing and enzyme activity. After this time the same oven was set to $65^{\circ} \mathrm{C}$ and the samples kept there for 72 hours.

The root and stem base samples were ground separately in Willey mills with $1 \mathrm{~mm}$ sieves, placed in plastic containers, identified and stored. NSC chemical analysis followed the method described by Smith (1973) and total N was analyzed according AOAC (1990).

Data was tested for error normality and variance homogeneity and the statistical analysis was carried out with a SAS statistical package (STATISTICAL ANALYSIS SYSTEM, 2003), in the GLM procedure for the model of subdivided plots, the doses of $\mathrm{N}$ being considered the main treatment and the depth of root collection as sub-plot. Statistical analyses were carried out separately for each season evaluated (fall, spring and summer). The means were compared by the F-test and by the mean SNK test for the roots and by Tukey test for NSC and total $\mathrm{N}$ to the significance level of $5 \%$.

\section{Results and Discussion}

Table 1 shows the results from the evaluation at the experiment's outset (April, 2007). Mean and representative samplings were done all over the experimental area with six repetitions for each collection depth. It was initially observed that the root system biomass was spread over three layers: 0 to $10 \mathrm{~cm}(75.13 \%), 10$ to $20 \mathrm{~cm}(15.21 \%)$ and 20 to $40 \mathrm{~cm}(9.66 \%)$.

Table 1. Tanzania-grass root biomass $\left(\mathrm{kg} / \mathrm{m}^{3}\right)$, area $\left(\mathrm{mm}^{2}\right)$, diameter $(\mathrm{mm})$, length $(\mathrm{mm})$ e $\operatorname{root} \operatorname{density}\left(\mathrm{mm} / \mathrm{cm}^{3}\right)$ means at the outset of the experimental (April, 2007).

\begin{tabular}{lccccc}
\hline Depth & Root Biomass $\left(\mathrm{kg} / \mathrm{m}^{3}\right)$ & Area $\left(\mathrm{mm}^{2}\right)$ & Diameter $(\mathrm{mm})$ & Length $(\mathrm{mm})$ & Root Density $\left(\mathrm{mm} / \mathrm{cm}^{3}\right)$ \\
\hline $0-10 \mathrm{~cm}$ & 3.00 & 996.95 & 0.25 & 3972.20 & 5.06 \\
$10-20 \mathrm{~cm}$ & 0.61 & 1224.14 & 0.27 & 4485.77 & 5.71 \\
$20-40 \mathrm{~cm}$ & 0.39 & 1086.67 & 0.24 & 4612.48 & 2.94 \\
\hline
\end{tabular}

Source: Elaboration of the authors. 
The root system evaluations were carried out about two weeks after nitrogen was applied to pasture. In fall/2007, the root biomass was significant for collection depth (Table 2). No treatment effect $(\mathrm{P}>0.05)$ was observed for $\mathrm{N}$ dosage. When compared to the other layers, the largest root biomass was observed for depth $0-10 \mathrm{~cm}(\mathrm{P}<0.05)$. These studies agree with those found in the literature where the root biomass is concentrated in the soil's surface layer (CUNHA et al., 2010; SARMENTO et al., 2008).

Table 2. Root biomass $\left(\mathrm{kg} / \mathrm{m}^{3}\right)$, area $\left(\mathrm{mm}^{2}\right)$, diameter $(\mathrm{mm})$, length $(\mathrm{mm})$ and root density $\left(\mathrm{mm} / \mathrm{cm}^{3}\right)$ of Tanzania-grass that received $\mathrm{N}$ doses in three depths in fall/2007.

\begin{tabular}{lccccc}
\hline $\begin{array}{l}\text { Treatment } \\
\text { Doses of N }\end{array}$ & $\begin{array}{c}\text { Root Biomass } \\
\left(\mathrm{kg} / \mathrm{m}^{3}\right)\end{array}$ & Area $\left(\mathrm{mm}^{2}\right)$ & Diameter $(\mathrm{mm})$ & Length $(\mathrm{mm})$ & Root Density $\left(\mathrm{mm} / \mathrm{cm}^{3}\right)$ \\
\hline $0 \mathrm{~kg} \cdot \mathrm{ha}^{-1}$ & 1.78 & 1222.65 & 0.25 & 4800.11 & 5.02 \\
$50 \mathrm{~kg} \cdot \mathrm{ha}^{-1}$ & 1.32 & 1376.51 & 0.26 & 5164.09 & 5.53 \\
$100 \mathrm{~kg} \cdot \mathrm{ha}^{-1}$ & 1.81 & 1013.16 & 0.26 & 4174.77 & 4.49 \\
$150 \mathrm{~kg} \cdot \mathrm{ha}^{-1}$ & 1.23 & 1122.15 & 0.28 & 3981.76 & 4.25 \\
\hline Depths & & & & $5186.74 \mathrm{a}$ & \\
\hline $0-10 \mathrm{~cm}$ & $3.71 \mathrm{a}$ & $1412.56 \mathrm{a}$ & 0.27 & $3970.12 \mathrm{~b}$ & $5.06 \mathrm{~b}$ \\
$10-20 \mathrm{~cm}$ & $0.78 \mathrm{~b}$ & $1043.35 \mathrm{~b}$ & 0.26 & $4433.69 \mathrm{~b}$ & $2.89 \mathrm{c}$ \\
$20-40 \mathrm{~cm}$ & $0.11 \mathrm{c}$ & $1162.44 \mathrm{ab}$ & 0.26 & 21.8 & 22.3 \\
\hline $\mathrm{CV}(\%)$ & 37.8 & 29.2 & 9.4 &
\end{tabular}

Means followed by different small letters in the same column differ by the SNK test $(\mathrm{P}<0.05)$.

Source: Elaboration of the authors.

Although no significant difference was observed saw a trend that the root biomass increased with $\mathrm{N}$ dose of $100 \mathrm{~kg} \mathrm{ha}^{-1}$ but then it decreased markedly for a dose of $150 \mathrm{~kg} \mathrm{ha}^{-1}$. These results agree with those from Sarmento et al. (2005) who when evaluating the effect of $\mathrm{N}$ on the root system of IPR86 Milênio grass found maximum post-grazing root mass for a dose of $197 \mathrm{~kg} \mathrm{ha}^{-1}$. Another hypothesis verified concerns the slow initial growth of the plant root after nitrogen fertilization, possibly because $\mathrm{N}$ was used for the development of aerial phytomass which led to a delay in the production and growth of new roots. As a matter of fact, $81.7 \%$ of the root biomass was found in the surface layer $(0-10 \mathrm{~cm}$ deep), $15.7 \%$ from 10 to $20 \mathrm{~cm}$ and $2.6 \%$ from 20 to $40 \mathrm{~cm}$.

Working with clay red latosoil, Kanno, Macedo e Bono (1999) did not detect an increase in biomass production of five tropical grass pastures under continuos grazing when the $\mathrm{N}$ dosage was increased from 50 to $100 \mathrm{~kg} \mathrm{ha}^{-1}$. However, there was some improvement in its distribution over the soil profile since the roots went deeper for the $100 \mathrm{~kg} \mathrm{ha}^{-1}$ dose. These results agree with those obtained considering that the fertilization was applied in three installments observing an increase in $\mathrm{N}$ dosage from 50 to 100 $\mathrm{kg} \mathrm{ha}^{-1}$ (Table 2).

The root area showed significant effect for collection depth of $0-10 \mathrm{~cm}$ the greatest root area $(\mathrm{P}<0.05)$ was in the $10-20 \mathrm{~cm}$ layer (Table 2). Root diameter did not show significant effects for either treatments or collection depths. Plant nutrient intake occurs because of the root growth and though its branches. Therefore, the amount of nutrient absorbed is determined by the total surface area of the roots and by the absorption rate per unit surface area (DO VALE, et al., 2013).

Root length and density showed significant effect for evaluated collection depths (Table 2). Layer 0-10 cm showed the greatest root length, root biomass and root density $(\mathrm{P}<0.05)$ when compared to the other layers studied. 
$\mathrm{N}$ deficiency is detrimental to the growth of the root system (GIACOMINI et al., 2005). Muller et al. (2001) verified a reduced root density in a degraded pasture of grass variety guinea grass (963 roots counted in 50 x $50 \mathrm{~cm}$ screens) when compared to the productive pasture (1,190 roots). In this experiment, such effect was not seen because the pasture was quite strong following regrowth, did not show signals of degradation and featured good soil fertility, which did not show statistical differences with respect to the witness treatment of the evaluated $\mathrm{N}$ dosages.

Besides water and ion absorption, the primary role of roots is to fix the plant on the soil. Functions like storage, synthesis of growth, dispersion and propagation regulators may be considered secondary. Also, roots of plants cultivated under adequate soil conditions may be considered important sources of regrowth matter (LAVRES JUNIOR; MONTEIRO, 2003).

In spring, root biomass, area, length and root density did not show differences for the effect of $\mathrm{N}$ dosage however it was significant for root collection depth root biomass and root density (Table 3). The root diameter showed effects for $\mathrm{N}$ dosage and collection depths. The largest count of roots was found in the $0-10 \mathrm{~cm}$ layer with respect to the other layers. Root density presented effects for collection depth. Depths from 20 to $40 \mathrm{~cm}$ presented the least root density $(\mathrm{P}<0.05)$ when compared to the other layers. These results agree with those obtained in the literature where the root biomass is concentrated in the soil's surface layer (SARMENTO et al., 2008).

Table 3. Root biomass $\left(\mathrm{kg} / \mathrm{m}^{3}\right)$, area $\left(\mathrm{mm}^{2}\right)$, diameter $(\mathrm{mm})$, length $(\mathrm{mm})$ and root density $\left(\mathrm{mm} / \mathrm{cm}^{3}\right)$ of Tanzania-grass as a function of three depths in spring/2007.

\begin{tabular}{lccccc}
\hline Treatment & Root biomass $\left(\mathrm{kg} / \mathrm{m}^{3}\right)$ & Area $\left(\mathrm{mm}^{2}\right)$ & Diameter $(\mathrm{mm})$ & Length $(\mathrm{mm})$ & Root Density $\left(\mathrm{mm} / \mathrm{cm}^{3}\right)$ \\
\hline Doses of N & & & & & \\
0 & 1.43 & 1213.97 & $0.27 \mathrm{~b}$ & 4517.82 & 4.75 \\
$50 \mathrm{~kg} \cdot \mathrm{ha}^{-1}$ & 1.19 & 1207.92 & $0.27 \mathrm{~b}$ & 4506.99 & 4.80 \\
$100 \mathrm{~kg} \cdot \mathrm{ha}^{-1}$ & 1.75 & 1215.09 & $0.30 \mathrm{a}$ & 4042.33 & 4.19 \\
$150 \mathrm{~kg} \cdot \mathrm{ha}^{-1}$ & 1.32 & 1256.94 & $0.30 \mathrm{a}$ & 4202.54 & 4.43 \\
\hline Depths & & & & & \\
$0-10 \mathrm{~cm}$ & $3.12 \mathrm{a}$ & 1202.13 & $0.28 \mathrm{~b}$ & 4370.46 & $5.57 \mathrm{a}$ \\
$10-20 \mathrm{~cm}$ & $0.95 \mathrm{~b}$ & 1203.48 & $0.30 \mathrm{a}$ & 4076.69 & $5.19 \mathrm{a}$ \\
$20-40 \mathrm{~cm}$ & $0.21 \mathrm{c}$ & 1264.83 & $0.28 \mathrm{~b}$ & 4505.12 & $2.87 \mathrm{~b}$ \\
\hline $\mathrm{CV}(\%)$ & 33.3 & 12.4 & 7.6 & 12.5 & 12.9 \\
\hline
\end{tabular}

Means followed by different small letters in the same column differ by the SNK test $(\mathrm{P}<0.05)$.

Source: Elaboration of the authors.

It was found that although the $\mathrm{N}$ dosage did not show statistical differences the root biomass showed the same tendency as seen for fall, that is, it was observed an increase of the $\mathrm{N}$ dosage from 50 to $100 \mathrm{~kg} \mathrm{ha}^{-1}$. These results agree with those found by Kanno, Macedo e Bono (1999) and Sarmento et al. (2008). Most of the collected root biomass was found in the surface layer from 0 to $10 \mathrm{~cm}$ deep
(73.0\%), from 10 to $20 \mathrm{~cm}(22.0 \%)$ and from 20 to $40 \mathrm{~cm}(5.0 \%)$.

The largest concentration of roots of permanent grasses is at the soil surface mainly at the $0-10 \mathrm{~cm}$ layer but the density of those roots varies among the grass species (KANNO; MACEDO; BONO, 1999; HODGSON, 1990; GIACOMINI et al., 2005). The root growth is affected by the soil nutrient 
concentration, by water availability, by the soil's physical condition and by the techniques employed in the handling of the plant (GUENNI; MARIN; BARUCH, 2002).

In summer/2008 the root biomass and root density showed effects only for root collection depth (Table 4). The largest count of roots was found in the $0-10 \mathrm{~cm}$ layer $(\mathrm{P}<0.05)$ with respect to the other layers. These results agree with those obtained from the literature where the root biomass is concentrated on the soil surface. In the $0-10 \mathrm{~cm}$ deep layer we observed the same behavior as in the other seasons evaluated (fall and spring) where the root biomass was visibly reduced with higher dosages of $\mathrm{N}$. The root growth is affected by soil nutrient concentration, by water availability, by ground physical condition and by the techniques employed in the handling of the plants (DO VALE et al., 2013; CUNHA et al., 2010). For summer, most of the sampled root biomass was found in the surface layer from 0 to $10 \mathrm{~cm}$ deep $(83.0 \%)$, from 10 to $20 \mathrm{~cm}(10.0 \%)$ and from 20 to $40 \mathrm{~cm}(7.0 \%)$.

Table 4. Root biomass $(\mathrm{RB})\left(\mathrm{kg} / \mathrm{m}^{3}\right)$, area $\left(\mathrm{mm}^{2}\right)$, diameter $(\mathrm{mm})$, length $(\mathrm{mm})$ and root density $\left(\mathrm{mm} / \mathrm{cm}^{3}\right)$ of Tanzaniagrass as a function of three depths in summer/2007.

\begin{tabular}{lccccc}
\hline Treatment & Root biomass $\left(\mathrm{kg} / \mathrm{m}^{3}\right)$ & Area $\left(\mathrm{mm}^{2}\right)$ & Diameter $(\mathrm{mm})$ & Length $(\mathrm{mm})$ & Root Density $\left(\mathrm{mm} / \mathrm{cm}^{3}\right)$ \\
\hline Doses of N & & & & & \\
0 & 0.98 & 2099.69 & 0.32 & 5953.88 & 6.14 \\
$50 \mathrm{~kg} \cdot \mathrm{ha}^{-1}$ & 0.99 & 1842.57 & 0.32 & 5146.47 & 5.58 \\
$100 \mathrm{~kg} \cdot \mathrm{ha}^{-1}$ & 1.51 & 1784.96 & 0.32 & 5025.14 & 5.38 \\
$150 \mathrm{~kg} \cdot \mathrm{ha}^{-1}$ & 1.25 & 1658.03 & 0.30 & 4787.67 & 5.25 \\
\hline Depths & & & & & \\
$0-10 \mathrm{~cm}$ & $2.96 \mathrm{a}$ & 1969.64 & 0.31 & 5583.77 & $6.84 \mathrm{a}$ \\
$10-20 \mathrm{~cm}$ & $0.37 \mathrm{~b}$ & 1701.22 & 0.33 & 5062.18 & $6.34 \mathrm{a}$ \\
$20-40 \mathrm{~cm}$ & $0.22 \mathrm{~b}$ & 1868.08 & 0.30 & 5038.92 & $3.58 \mathrm{~b}$ \\
\hline $\mathrm{CV}(\%)$ & 39.8 & 16.7 & 14.4 & 22.7 & 21.2 \\
\hline
\end{tabular}

Means followed by different small letters in the same column differ by the SNK test $(\mathrm{P}<0.05)$.

Source: Elaboration of the authors.

The largest concentration of permanent grasses is at the soil's surface layer. Sarmento et al. (2008) concluded that $60 \%$ of the Panicum maximum cv. IPR-86 Milênio root system was concentrated in the 0-10 cm deep layer.

The root area, the diameter and the length of roots did not present effects for either $\mathrm{N}$ dosage or collection depth (Table 4). Sarmento et al. (2008) found that the maximum root growth in terms of length density was obtained for a dosage of $192 \mathrm{~kg}$ $\mathrm{ha}^{-1}$ of $\mathrm{N}$ and in terms of mass density for a dosage of $197 \mathrm{~kg} \mathrm{ha}^{-1}$. Singh (1999) detected an increase in the root length for Panicum maximum cv. Makueni up to a dosage of $200 \mathrm{~kg} \mathrm{ha}^{-1}$ of $\mathrm{N}$.
Root density presented effects for the collection depth (Table 4). The least root density was found for the depth of $20-40 \mathrm{~cm}(\mathrm{P}<0.05)$ when compared to the other layers and it was observed that $\mathrm{N}$ dosages did not change density.

Nitrogen fertilization usually develops the aerial part more than the root of the plant (TERUEL et al., 2000). When a severe nitrogen deficiency occurs, the addition of that nutrient should result in an increase in the root mass but when the supply is too high, the root mass is likely to be reduced (GIACOMINI et al., 2005). Batista; Monteiro (2006a); Santos et al. (2001), working in greenhouse and using silica as substrate have estimated that the $\mathrm{N}$ dosage required 
for maximum dry mass production from the roots of Brachiaria brizantha cv. Marandu were, on the average, $379 \mathrm{mg} / \mathrm{L}$. On the other hand, on an experiment conducted in a condition similar as above, Lavres Junior e Monteiro (2003) estimated that in order to obtain the maximum root length for Panicum maximum cv. Mombaça it is necessary to supply dosages of $\mathrm{N}$ higher than those used which were $28 ; 112 ; 210 ; 336$ e $462 \mathrm{mg} \mathrm{L}^{-1}$.

Chaparro, Sollenberger e Jones Junior (1995) verified at the end of the second year of experimentation a linear decrease in the production of root dry mass with an increase in the frequency and intensity of the defoliation of the dwarf elephant grass probably as a consequence of a lack of energy from photosynthesis. Plants grazed down to $10 \mathrm{~cm}$ above ground surface every three weeks showed the least root mass density while plants grazed to $46 \mathrm{~cm}$ every 12 weeks showed root densities 30 times as great $\left(24 \times 733 \mathrm{~g} / \mathrm{m}^{3}\right.$ MS). Similar results were found by Almeida et al. (2000) who in larger forage supply to livestock observed that the plants showed a more developed root system.

Pagotto, Imhoff e Corsi (2002) detected a reduction in the root system growth rate of Tanzaniagrass irrigated immediately after grazing. Virtually no growth occurred for three days after grazing while 30 days after grazing the live root density was about $9.2 ; 14.2$ e $16.5 \mathrm{mg} / 100 \mathrm{~cm}^{3}$ for post-grazing residues of $1,000,2,500 \mathrm{e} 4,000 \mathrm{~kg} \cdot \mathrm{ha}^{-1}$ of green dry mass, respectively.

Harris (1978) reported that the reduction in root growth immediately after grazing caused by frequent and intense defoliation may cause a reduction in plant water and nutrient absorption. Late, Teruel et al. (2000) stressed that such loss of part of the root system should not be seen only by its negative aspect since it looks like a forage plant's physiological strategy for a quick recovery of the aerial part and a reduction of the root system carbon demand.
Sarmento et al. (2005), evaluating the access of grazed Panicum maximum IPR-86 Milênio under the effect of nitrogen doses $(0,150,300$ e $450 \mathrm{~kg}$ $\mathrm{ha}^{-1}$ of $\mathrm{N}$ ) in the root system found that the length and mass densities of roots showed maximum values for the doses of 204, 206, 192 e $197 \mathrm{~kg} \mathrm{ha}^{-1}$ of $\mathrm{N}$, respectively. The author detected that the root growth (in length density) increased up to 29 days under pasture for doses of 0,150 e $300 \mathrm{~kg} \mathrm{ha}^{-1}$ of $\mathrm{N}$ and at a dose of $450 \mathrm{~kg} \mathrm{ha}^{-1}$ of $\mathrm{N}$, the increase was linear.

Nitrogen deficiency reduces root system growth (GIACOMINI et al., 2005). Muller et al. (2001) verified a reduced root density in a degraded pasture of grass variety guinea grass $(9,963$ roots counted in 50 x $50 \mathrm{~cm}$ screens) as compared to a productive pasture (1,190 roots). In the current experiment, because the pasture was had been established for five years, was strong following regrowth, had a good plant standing and regrowth carbon content it was not possible to verify marked differences for all evaluated parameters in the absence of nitrogen fertilization. This can be associated to a good quantity of dry mass from leaf blades in the post-grazing and to the residual leaf area index (30 from ground level). Thornton and Millard (1996) concluded that the root dry mass of species Festuca rubra and Lolium perene is inversely proportional to defoliation intensities and therefore directly proportional to the residual leaf area index of the grass. Since in all treatments of the present experiment these two handling rules were respected, no differences were observed for the root system.

Although no statistical difference was found it was observed that the root biomass presented a trend for mass accumulation for $\mathrm{N}$ dosages up to $100 \mathrm{~kg} \mathrm{ha}^{-1}$ in all seasons evaluated (Tables 2, 3 and 4). Regardless of the $\mathrm{N}$ dosage about $80 \%$ of the root system of the Tanzania grass was concentrated on the $0-10 \mathrm{~cm}$ deep layer.

The few works on forage plants under grazing conditions that include a study of roots are usually 
limited to the evaluation of the dry mass of the roots at the end of the experiment. Studies that evaluate the dynamics of the root system should be therefore encouraged.

\section{Organic reserves and stem base}

Results of root organic reserves show that the largest accumulation of NSC occurs for N fertilization between 50 and $100 \mathrm{~kg} \mathrm{ha}^{-1}$. These dosages presented displayed similarities between them (Table 5). The reduced level of NSC in the treatment with $150 \mathrm{~kg} \cdot \mathrm{ha}^{-1}$ of $\mathrm{N}$ can be explained by fast growth certainly leading to the greater development of leaves and stem due to the greater availability of $\mathrm{N}$ from mineral fertilization resulting in the forage plant using larger volumes of NSC for regrowth Volenec, Ourry e Joern (1996).

Table 5. Levels of Non-Structural Carbohydrates (NSC) and total N in Tanzania-grass roots as a function of doses of $\mathrm{N}$, depth of collection and season.

\begin{tabular}{llc}
\hline Treatment & $\begin{array}{c}\text { NSC } \\
\mathrm{g} / \mathrm{kg}\end{array}$ & $\begin{array}{c}\text { Total N } \\
\mathrm{g} / \mathrm{kg}\end{array}$ \\
\hline $0 \mathrm{~kg} \cdot \mathrm{ha}^{-1}$ of N & $0.47 \mathrm{bc}$ & 5.70 \\
$50 \mathrm{~kg} \cdot \mathrm{ha}^{-1}$ of N & $0.65 \mathrm{a}$ & 6.00 \\
$100 \mathrm{~kg} \cdot \mathrm{ha}^{-1}$ of N & $0.55 \mathrm{ab}$ & 5.70 \\
$150 \mathrm{~kg} \cdot \mathrm{ha}^{-1}$ of N & $0.38 \mathrm{c}$ & 6.10 \\
Depth of collection & & \\
$0-10 \mathrm{~cm}$ & $0.44 \mathrm{~b}$ & $7.60 \mathrm{a}$ \\
$10-20 \mathrm{~cm}$ & $0.50 \mathrm{~b}$ & $4.60 \mathrm{~b}$ \\
$20-40 \mathrm{~cm}$ & $0.59 \mathrm{a}$ & $4.30 \mathrm{~b}$ \\
Season & & \\
Fall & 0.53 & $5.70 \mathrm{~b}$ \\
Winter & 0.50 & $6.00 \mathrm{a}$ \\
\hline
\end{tabular}

Different letters in the same columns differ by the Tukey test $(\mathrm{P}<0.05)$.

Source: Elaboration of the authors.

For total N, there was no difference among the studied treatments. For collection depth (Table 5), the greatest NSC concentration was at the $20-40 \mathrm{~cm}$ layer, no difference occurring between $0-10 \mathrm{~cm}$ and $10-20 \mathrm{~cm}$ layers. However, for total N, the greatest concentration was found in layer $0-10 \mathrm{~cm}$, this behavior is similar to those found by Rodrigues et al. (2007), working with Brachiaria brizantha Xaraés grass. This result suggests that in addition to being storages of regrowth reserves, the roots use NSC for their own development while nitrogen reserves are primarily using for plant regrowth thus explaining the largest concentrations of NSC and $\mathrm{N}$ not occurring on the same layer. According to Volenec, Ourry e Joern (1996), stored N helps the regrowth of the aerial part of grasses and the defoliation causes a large difference in the sourcedrain relationships of $\mathrm{N}$, the root tissues acting as source and the regrowing of the aerial part as a powerful drain.

No difference for NSC was found among the studies seasons while total $\mathrm{N}$ was largest at spring due to the fact that fertilization was carried out at the rainy season (spring and summer) when the plants stored it as reserve. At the stem base (Table $6)$, the organic reserves showed the same trend. The levels of both NSC and total N were largest in the treatments with the largest dosages of $\mathrm{N}(150 \mathrm{~kg}$ $\left.\mathrm{ha}^{-1}\right)$. This is explained because the largest levels of DM show the largest concentrations of NSC, as well 
as, the largest levels of $\mathrm{N}$ respectively, because they have the largest count of green leaves, and thus of photo-synthesizing tissue, and the largest level of $\mathrm{N}$ due to nitrogen fertilization.

Table 6. Levels of Non-Structural Carbohydrates (NSC) at stem base of Tanzania-grass as a function of doses of N and season.

\begin{tabular}{lcc}
\hline Treatment & $\begin{array}{c}\mathrm{NSC} \\
\mathrm{g} / \mathrm{kg}\end{array}$ & $\begin{array}{c}\text { Total N } \\
\mathrm{g} / \mathrm{kg}\end{array}$ \\
\hline $0 \mathrm{~kg} \cdot \mathrm{ha}^{-1}$ of N & $0.69 \mathrm{~b}$ & $6.40 \mathrm{c}$ \\
$50 \mathrm{~kg} \cdot \mathrm{ha}^{-1}$ of N & $0.87 \mathrm{ab}$ & $8.60 \mathrm{~b}$ \\
$100 \mathrm{~kg} \cdot \mathrm{ha}^{-1}$ of N & $0.81 \mathrm{ab}$ & $9.90 \mathrm{ab}$ \\
$150 \mathrm{~kg} \cdot \mathrm{ha}^{-1}$ of N & $0.93 \mathrm{a}$ & $10.50 \mathrm{a}$ \\
Season & & \\
Fall & $1.26 \mathrm{a}$ & $9.40 \mathrm{a}$ \\
Winter & $0.39 \mathrm{~b}$ & $8.40 \mathrm{~b}$ \\
\hline
\end{tabular}

Different letters in the same columns differ by the Tukey test $(\mathrm{P}<0.05)$.

Source: Elaboration of the authors.

NSC and total $\mathrm{N}$ concentrations were largest in fall because of the weather conditions favorable to plant growth and their associated savings. However, in spring, besides being used for regrowth, SCN showed the largest decrease when compared with total N. This may suggest that NSC at stem base is more employed in regrowth than stored in the roots. According to Cecato et al. (2011), the volume of organic reserves is only slowly reduced in winter because the plant uses little of it. However, during spring, with the development of the aerial part, the reduction is increased but levels out soon because the plant begins to synthesize organic compounds. In summer the reserves grow and reach a maximum in fall, when it begins to decrease again.

\section{Conclusions}

Eighty percent of pasture root biomass is concentrated on the soil's surface layer. By reducing the NSC storage capacity of its roots nitrogen fertilization above $100 \mathrm{~kg} \mathrm{ha}^{-1}$ may encourage fast growth of a forage plant, however, favors NSC and total $\mathrm{N}$ storage at stem base. NSC and total N stem base concentrations were highest in fall, demonstrating that its consumption is largest in spring because of the conditions favorable to plant's growth. The plant shows its greatest total $\mathrm{N}$ reserves in the roots at the $0-10 \mathrm{~cm}$ layer and its largest NSC reserve at stem base.

\section{References}

ALMEIDA,E.X.; MARASCHIN, G.E.; HARTHMANN, O. E. L.; RIBEIRO FILHO, H. M. N.; SETELICH, E. A. Oferta de forragem de capim elefante anão "Mott" e a dinâmica da pastagem. Revista Brasileira de Zootecnia, Viçosa, MG, v. 29, n. 5, p. 1281-1287, 2000.

ASSOCIATION OF OFFICIAL ANALYTICAL CHEMISTS - AOAC. Official methods of analysis. $15^{\text {th }}$ ed. Gaithersburg, Estados Unidos, Richmond, 1990. $1298 \mathrm{p}$.

BARBOSA, R. A.; NASCIMENTO JUNIOR, D.; EUCLIDES, V. P. B.; SILVA, S. C. da; ZIMMER, A. H.; TORRES JUNIOR, R. A. A. Capim-tanzânia submetido a combinações entre intensidade e freqüência de pastejo. Pesquisa Agropecuária Brasileira, Brasília, v. 42, n. 3, p. 329-340, 2007.

BATISTA, K.; MONTEIRO, F. A. Respostas morfológicas e produtivas do capim-marandu a doses combinadas de nitrogênio e enxofre. Revista Brasileira de Zootecnia, Viçosa, v. 35, n. 4, p. 1281-1288, 2006 a.

Sistema radicular do capim-marandu, considerando as combinações de doses de nitrogênio e enxofre. Revista Brasileira de Ciência do Solo, Viçosa, v. 30, n. 1, p. 821-828, 2006 b. 
CECATO, U.; GALBEIRO, S.; PARIS, W.; SOARES FILHO, C. V.; TEIXEIRA, S. Uso de nitrogênio em pastagens. In: SIMPÓSIO DE PRODUÇÃO ANIMAL A PASTO, 1., 2011, Maringá. Anais... Maringá: Sthampa, 2011. p. 117-161.

CHAPARRO, C. J.; SOLLENBERGER, L. E.; JONES JUNIOR, C. S. Defoliation effects on "Mott" elephant grass productivity and leaf percentage. Agronomy Journal, Madison, v. 87, n. 5, p. 981-985, 1995.

CORRÊA, A. R. Forrageiras: aptidão climática do Estado do Paraná. In: MONTEIRO, A .L. G.; MORAES, A.; CORRÊA, E. A. S. et al. Forragicultura no Paraná. Londrina: Comissão Paranaense de Avaliação de Forrageiras, 1996. cap. 2, p. 15-22.

CUNHA, F. F.; RAMOS, M. M.; ALENCAR, C. A. B.; MARTINS, C. E.; COSER, A. C.; OLIVEIRA, R. A. Sistema radicular de seis gramíneas irrigadas em diferentes adubações nitrogenadas e manejos. Acta Scientiarum. Agronomy, Maringá, v. 32, n. 2, p. 351-357, 2010.

DO VALE, J. C.; MAIA, C.; FRITSCHE-NETO, R.; MIRANDA, G. V.; CAVATTE, P. C. Genetic response of traits relationship to components of nitrogen and phosphorus use efficiency in maize. Acta Scientiarum. Agronomy, Maringá, v. 35, n. 1, p. 31-38, 2013.

EMPRESA BRASILEIRA DE PESQUISA AGROPECUÁRIA - EMBRAPA. Sistema brasileiro de classificação de solos. 2. ed. Rio de Janeiro: Embrapa Solos, 2006. 306 p.

GIACOMINI, A. A.; MATTOS, W. T.; MATTOS, H. B.; WERNER, J. C.; CUNHA, E. A.; CARVALHO, D. D. Crescimento de raízes dos capins Aruana e Tanzânia submetidos a duas doses de nitrogênio. Revista Brasileira de Zootecnia, Viçosa, v. 34, n. 4, p. 1109-1120, 2005.

GUENNI, O.; MARIN, D.; BARUCH, Z. Response to drought of five brachiaria species. I. Biomass production, leaf, growth, root distribution, water use and forage quality. Plant and Soil, The Hague, v. 243, n. 2, p. 229-241, 2002.

HARRIS, W. Defoliation as a determinant of the growth, persistence and composition of pasture. In: WILSON, J. R. (Ed.). Plant relations in pastures. Melbourne: CSIRO, 1978. p. 67-85.

HODGSON, J. Grazing management: science into practice. New York: john Wiley, 1990.

HUMPHREYS, L. R. Tropical pasture utilization. Australia: Cambridge University Press, 1991. 206 p.

KANNO, T.; MACEDO, M. C. M.; BONO, J. A. M. Root biomass of five tropical grass pastures under continuous grazing in Brasilian savannas. Grassland Science, Kyoto, v. 45, n. 1, p. 9-14, 1999.
LAVRES JUNIOR, J.; MONTEIRO, F. A. Perfilhamento, área foliar e sistema radicular do capim-Mombaça submetido a combinações de doses de nitrogênio e potássio. Revista Brasileira de Zootecnia, Viçosa, v. 32, n. 5, p. 1068-1075, 2003.

MULLER, M. M. L.; GUIMARÃES, M. F.; DESJARDINS, T.; MARTINS, P. F. S. Degradação de pastagens na Região Amazônica: propriedades físicas do solo e crescimento de raízes. Pesquisa Agropecuária Brasileira, Brasília, v. 36, n. 11, p. 1409-1418, 2001.

PAGOTTO, D. S.; IMHOFF, S.; CORSI, M. Soil compaction versus cow-stocking rates on an irrigated grazing system. Advances in GeoEcology, Reiskirchen, v. 35, n. 1, p. 397-406, 2002.

RODRIGUES, R. C.; MOURÃO, G. B.; VALINOTE, A. C.; HERLING, V. R. Reservas orgânicas, relação parte aérea-raiz e c-n e eliminação do meristema apical no capim-Xaraés sob doses de nitrogênio e potássio. Ciência animal Brasileira, Goiânia, v. 8, n. 3, p. 505-514, 2007.

SANTOS, I. P. A.; PINTO, J. C.; SIQUEIRA, J. O.; MORAIS, A. R.; CURI, N.; EVANGELISTA, A. R. Resposta a fósforo, micorriza e nitrogênio de Braquiarão e amendoim forrageiro consorciados. 1. Rendimento de matéria seca da parte aérea e da raiz. Ciências Agrotécnicas, Lavras, v. 25, n. 5, p. 1206-1215, 2001.

SARMENTO, P.; RODRIGUES, L. R. A.; LUGÃO, S. M. B.; CRUZ, M. C. P.; CAMPOS, F. P.; FERREIRA, M. E. Respostas agronômicas e morfológicas de Panicum maximum Jacq. Cv. IPR-86 Milênio, sob pastejo, à adubação nitrogenada. Boletim da Indústria Animal, Nova Odessa, v. 62, n. 4, p. 333-346, 2005.

SARMENTO, P.; RODRIGUES, L. R. de A.; LUGÃO, S. M. B.; CRUZ, M. C. P.; CAMPOS, F. P.; FERREIRA, M. E.; OLIVEIRA, R. F. Sistema radicular do Panicum maximum Jacq. Cv. IPR-86 Milênio adubado com nitrogênio e submetido à lotação rotacionada. Revista Brasileira de Zootecnia, Viçosa, v. 37, n. 1, p. 27-34, 2008.

STATISTICAL ANALYSIS SYSTEM INSTITUTE SAS. SAS/STAT Procedure guide personal computers. 9. ed. Cary, NC. Inst, 2003. 334 p.

SINGH, K. A. Effect of nitrogen levels on yield, root biomass distribution, nitrogen recovery by forage grasses and changes in soil properties of acid Inceptisol. Indian Journal of Agricultural Sciences, New Delhi, v. 69, n. 8, p. 551-554, 1999.

SMITH, D. The nonstructural carbohydrates. In: BUTTLER, G. W.; BAILEY, R. W. (Ed.). Chemistry and biochemistry of herbage. London: Academic Press, 1973. p. 105-155. 
TERUEL, D. A.; DOURADO NETO, D.; HOPMANS, J. W.; REICHARDT, K. Modelagem matemática como metodologia de análise do crescimento e arquitetura de sistemas radiculares. Scientia Agricola, Piracicaba, v. 57, n. 4 , p. 683-691, 2000.

THORNTON, B.; MILLARD, P. Effects of severity of defoliation on root functioning in grasses. Journal of Range Management, Tucson, v. 49, n. 5, p. 443-447, 1996.
VOLENEC, J. J.; OURRY, A.; JOERN, B. C. A role to nitrogen reserves in the regrowth of forages and tolerance for stress. Physiologia Plantarum, Sweden, v. 97, n. 1, p. 185-193, 1996.

WERNER, J. C.; PAULINO, V. T.; CANTARELLA, H.; ANDRADE, N. de O.; QUAGGIO, J. A. Forrageiras. In: RAIJ, B. V.; CANTARELLA, H.; QUAGGIO, J. A.; FURLANI, A. M. C. Recomendações de adubação e calagem para o Estado de São Paulo. 2. ed. Campinas, Instituto Agronômico e Fundação IAC, 1996. p. 263-273. (Boletim técnico, 100). 